\title{
バイオミメティックなアプローチによるソフト マテリアルの濡れ性と摩擦特性の制御
}

\author{
小林 元康 $^{1}$ 高原 淳 $^{1,2}$ \\ 1独立行政法人科学技術振興機構 ERATO 俨 819-0395 福岡県福岡市西区元岡 744 \\ '九州大学先導物質化学研究所 『 819-0395 福岡県福岡市西区元岡 744
}

(2010 年 3 月 11 日受理)

\section{Wettability and Friction Control of Soft Materials Based on Biomimetic Approach}

\author{
Motoyasu Kobayashi ${ }^{1}$ and Atsushi TaKahara ${ }^{1,2}$ \\ ${ }^{1}$ Japan Science Technology Agency, ERATO, Takahara Soft Interfaces Project, 744 Motooka, Nishi-ku, Fukuoka 819-0395 \\ ${ }^{2}$ Institute for Materials Chemistry and Engineering, Kyushu University, 744 Motooka, Nishi-ku, Fukuoka 819-0395
}

(Received March 11, 2010)

\begin{abstract}
Since surfaces and interfaces of soft materials ("soft interface") play an important role in various technological applications, precise control of soft interfaces would greatly promote the innovation of future science and technology. This study investigated the design of soft interfaces by biomimetic approach such as nano-texturing of polymer thin films, and high-density polymer brush immobilization to achieve the control of wettability and tribological characteristics. The anisotropic wetting which can preset on the desert beetle surface was designed by micropatterned fluoroalkylsilane monolayer surfaces consisting of a hydrophilic/hydrophobic area. The lotus leaf like nano-texture was fabricated on the fluoropolymer film surface by nanoimprinting technique to reveal lotus effect with an water and oil repellency based on the Cassie mode wetting. Super hydrophilic surface was fabricated on the silicon wafer by surface grafting of zwitter-type polyelectrolyte bearing phosphorylcholine groups which exist as a hydrophilic group in biomembrane. A water droplet on the polyelectrolyte brush surface showed a very low contact angle, and the air bubble and hydrocarbon liquid were hardly attached to the brush surface in the hydrated state. The phosphobetaine-type polyelectrolyte brush showed a low friction coefficient in humid air and aqueous solution because the hydrated brush formed a boundary layer for water lubrications.
\end{abstract}

KEYWORDS : soft interfaces, wettability, nanoimprinting, polymer brush, tribology

\section{1. 緒}

\section{言}

雨上がりに蓮の葉や里芋の葉の表面を観察すると，葉 の表面で水滴がはじかれコロコロと転がる様子をみるこ とができる (Fig. 1)。これは蓮の葉表面に形成される微 細構造とワックス状物質の相乗効果により ${ }^{1)}$, 水滴と凹 の部分に空気が入りこむためである。これは撥水だけで なく防污性やセルフクリーニングにも寄与している。ヤ モリの指先には微細な剛毛が密集しており, さらにその

E-mail : takahara@cstf.kyushu-u.ac.jp
先端が直径 $200 \mathrm{~nm}$ ほどの扁平板状の構造をしているこ とで指先と壁との密着性が極めて高く，ファンデルワー ルスカによる接着力が最大限に発揮されている ${ }^{2}$ 。ま た，砂漠に生息する甲虫（ゴミムシダマシ）の中には体 表面に親水性の微細な突起を持ち, 霧を集めて水滴にし ては撥水性の体表面上で転がして口元に運ぶ生物がい る ${ }^{3)}$ ここのよう自然界にはソフトマテリアルの表面微 細構造と濡れ特性をうまく組み合わせ，防污性や集水性 などを発現するしくみが多数見受けられる。こうした機 能は光リソグラフィーやナノインプリント法により作製 する微細構造と, 有機単分子膜やポリマーブラシなどか 


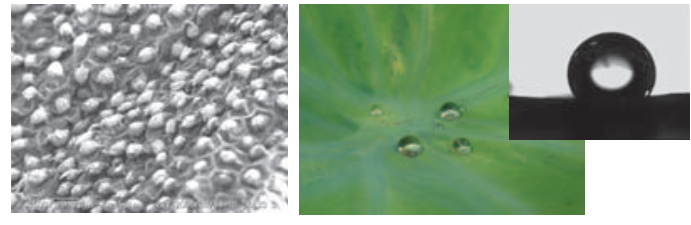

Fig. 1. (color online). SEM image (left) and water droplets rolling on the aroid leaf surface (right). (a)

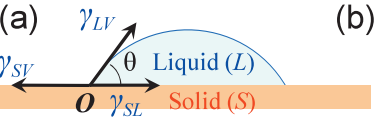

(b)

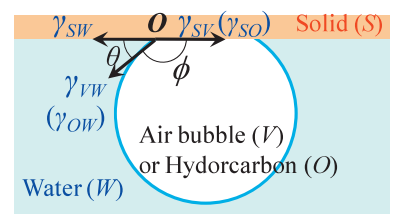

Fig. 2. (color online). Contact angles of (a) liquid on the solid surface and (b) air (or hydrocarbon) bubble in water.

固体表面の「化学構造」，「表面粗さ」，「表面分子運動 性」の3つの因子によって支配される。

\section{1 固体表面の濡れ性と化学構造の関係}

Owens-Wendt らの式により ${ }^{4)}$ ，表面自由エネルギーは 非極性の分散力成分 $\gamma^{\mathrm{d}}$ と, 極性力成分 $\gamma^{\mathrm{p}}$ との和として 表される。

$$
\gamma=\gamma^{\mathrm{d}}+\gamma^{\mathrm{p}}
$$

フルオロアルキル基が表面を覆うフルオロアルキル系 単分子膜は著しく低い $\gamma^{\mathrm{d}}$ を示し, 一方, 極性のアミド 基や水酸基を高密度で有するナイロンやポリビニルアル コールは高い $\gamma^{\mathrm{p}}$ を示す。このように表面自由エネルギ 一は界面に存在する官能基の種類に大きく依存してい る。実際, 蓮や里芋の葉の表面は炭化水素系ワックスの ような極性官能基の少ない物質で覆われており，表面の 撥水性に寄与している。表面自由エネルギーについては この他にも $\mathrm{Wu} ら$ ら $^{\mathrm{d}}$ と $\gamma^{\mathrm{p}}$ の調和平均の和として求め る式を提唱している ${ }^{5,6)}$ 。

$$
\begin{aligned}
(1 & +\cos \theta) \gamma_{L V} \\
& =4 \gamma_{L V}{ }^{\mathrm{d}} \gamma_{S}{ }^{\mathrm{d}} /\left(\gamma_{L V}{ }^{\mathrm{d}}+\gamma_{S}{ }^{\mathrm{d}}\right)+4 \gamma_{L V}{ }^{\mathrm{p}} \gamma_{S}{ }^{\mathrm{p}} /\left(\gamma_{L V}{ }^{\mathrm{p}}+\gamma_{S}{ }^{\mathrm{p}}\right)
\end{aligned}
$$

良く污れが付着しにくくなるような表面処理がされてい る。また，自然界でアメンボが水の上を歩行できるの も，ナンビア砂漠の甲虫が水を集めることができるの も，ドライアイで目が痛むのも表面の濡れ性が密接に関 連している。

固体表面の濡れ性を評価するための最も簡便な手段は 接触角測定である。Fig. 2 に示すように平滑な固体面 $S$ と液滴 $L$ (水の場合 $W$ ), あるいは固体-液体界面に存在 する気泡 $V$ と固体面のなす角 $\theta$ を接触角とし, YoungDupreの式を用いれば液体が気体と固体に接する所では 次のような力の釣り合いが成立している。

$$
\begin{aligned}
& \gamma_{L V} \cos \theta=\gamma_{S V}-\gamma_{S L} \\
& \gamma_{W V} \cos \phi=\gamma_{S W}-\gamma_{S V}
\end{aligned}
$$

ここで, $\gamma_{S L}, \gamma_{S V}, \gamma_{L V}$ はそれぞれ固-液界面, 固-気界 面，気一液界面の界面張力であり， $\phi$ は $\theta$ の補角である。 特に液体が水の場合, $\theta$ が $0^{\circ}$ に近く $\phi$ が $180^{\circ}$ に近い固 体表面を親水性， $\theta$ が $90^{\circ}$ 以上の固体表面を疎水性と呼 ぶ。そして, 固体表面における液体の接触角は主として

また, van Oss らは表面自由エネルギーを Lifshitz-van der Waals に基づく非極性相互作用 $\gamma^{\mathrm{LW}}$ と酸塩基相互作 用の和であるとし, 酸性成分 $\gamma^{+}$(電子受容性) と塩基 成分 $\gamma^{-}$(電子供与性) の寄与を考慮して次のように記 述している7)。

$$
\begin{aligned}
(1 & +\cos \theta) \gamma_{L V} \\
& =2\left\{\left(\gamma_{L V}{ }^{L W} \gamma_{S}{ }^{L W}\right)^{1 / 2}+\left(\gamma_{S}{ }^{+} \gamma_{L V}{ }^{-}\right)^{1 / 2}+\left(\gamma_{L V}{ }^{+} \gamma_{S}{ }^{-}\right)^{1 / 2}\right\}
\end{aligned}
$$

表面自由エネルギーの算出法については現在も様々な 議論があるが ${ }^{8}$, 極性高分子の表面についてはvan Oss らの提案が広く用いられている9

\section{2 表面のミクローナノ形状と接触角}

Fig. 1 の SEM 像からわかるように里芋の葉の表面に は多くのミクロな突起が存在している。このように固体 表面に液滴のサイズよりも小さな凹凸があると，例え表 面が同じ化学物質で構成されていても, 液滴の接触角 $\theta_{\mathrm{r}}$ （添え字の $\mathrm{r}$ は rough な表面であることを示す）は平 


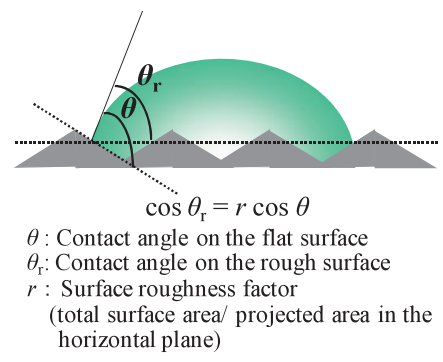

(a) Wenzel mode

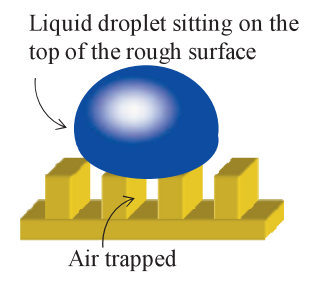

(b) Cassie mode

Fig. 3. (color online). (a) Homogeneous wetting regime on rough surfaces described by the Wenzel mode and (b) heterogeneous wetting regime described by the Cassie-Baxter equation.

らな表面上での接触角 $\theta$ とは異なってくる。

Fig. 3 （a）のような凹凸表面を仮定したとき，凹凸の 存在により表面積が $r$ 倍になるので凹凸面上の水平方向 の表面張力はそれぞれ $r$ 倍になる。そこで Wenzel ら $は^{10)}$, 液滴の見かけの接触角 $\theta_{\mathrm{r}}$ を次のように表した。

$$
\cos \theta_{r}=r\left(\gamma_{S V}-\gamma_{S L}\right) / \gamma_{L V}=r \cos \theta
$$

$r$ は表面積増倍因子であり, 凹凸面の表面積が平らな面 に比べ何倍になったかを表す。この因子は 1 よりも大き いから, 凹凸面上での液体のみかけの接触角 $\theta_{\mathrm{r}}$ は $\theta>90^{\circ}$ のときには $\theta$ より大きくなり, $\theta<90^{\circ}$ のときに は逆に小さくなる。すなわち, 固体表面の凹凸化によっ て撥水的な表面はより撥水的になり, 親水的な表面はよ り親水的になるのである。

しかし, 実際には表面の粗さが大きくなると液体が凹 凸に浸透しにくくなる。すなわち, Fig. 3（b）のように 固体と液体の界面に空気層が形成され, 接触角は増大す る。この場合, 表面粗さと接触角 $\theta_{\mathrm{r}}$ の関係はCassieBaxterの式 ${ }^{11)}$ で表される。

$\cos \theta_{\mathrm{r}}=Q_{1} \cos \theta_{1}+Q_{2} \cos \theta_{2}$

ここで $\theta_{\mathrm{i}}$ は成分 $i$ の接触角, $Q_{\mathrm{i}}$ は成分 $i$ の面積分率で ある。特に片方の成分が空気層の場合, $\theta_{2}=180^{\circ}$ であ り, $Q_{1}+Q_{2}=1$ なので, 式（7）は次のようになる。

$\cos \theta_{\mathrm{r}}=Q_{1} \cos \theta_{1}+Q_{1}-1$

里芋の葉の表面では水滴が丸くなるのは Fig. 1 の走査電 子顕微鏡像に示すように葉の表面に無数の細かい凹凸が 存在し, その凹凸が疎水性のワックスで覆われているた めで, 表面の凹凸による接触角の増大と対応している。 また木の表面をやすりでこすって粗くすると漆や塗料の ぬれがよくなるのもこの例である。このように表面に微 細な凹凸を付与することにより濡れ性を制御する様々な 試みがなされている。

\section{3 ナノインプリント法による表面形態制御}

高分子材料表面に微細な凹凸を賦与する方法としてナ

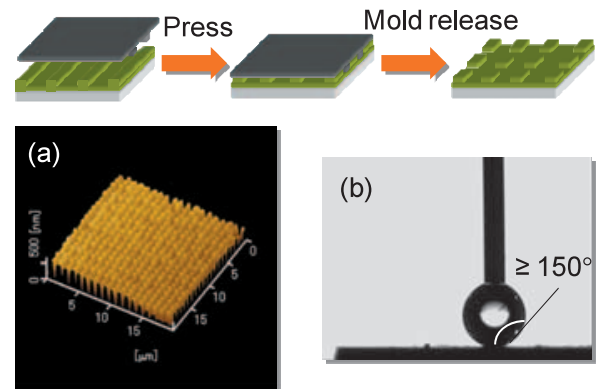

Fig. 4. (color online). Preparation of the rough surface on poly\{2-(perfluorooctyl)ethyl acrylate $\}$ film by nanoimprint technique:(a) AFM image of imprinted surface and (b) contact angle of water.

ノインプリントがある。ナノインプリントは高分子固体 表面にナノスケールで形状を賦与したモールドを押しつ けて表面にナノレベルの凹凸を賦与する方法である。こ こでは側鎖に結晶性の長鎖フルオロアルキル基を有する ポリ \{アクリル酸 2-(パーフルオロオクチル) エチル\} $\left(\mathrm{PFA}_{-} \mathrm{C}_{8}\right)$ 薄膜にシリコン製モールドのラインパターン （ライン幅約 $500 \mathrm{~nm}$ ）をナノインプリントにより転写し た ${ }^{12,13)}$ 。室温条件下, ラインパターンが直交するように 薄膜を連続インプリントしたところ, Fig. 4 に示すよう なナノメートルスケールの微細な凹凸が付与できた。こ の PFA-C 8 薄膜の対水接触角は $120^{\circ}$ であったが, ナノ インプリント後の表面の水の接触角は $150^{\circ}$ 以上, ヘキ サデカンの接触角は $90^{\circ}$ 以上にまで上昇した。SEM 像 より凸部の面積分率は 0.30 と見積もられたので, Cassie-Baxterの（8）式に $Q_{1}=0.30$ と $\theta_{1}=120^{\circ}$ を代入 すると $\theta_{\mathrm{r}}=148^{\circ}$ となり実測值とほほ一致したことから, 濡れ性が Cassie-Baxter の式に従うことが明らかである。

\section{3. 表面の濡れ性の精密制御}

\section{1 有機単分子薄膜による異方性濡れ}

飽和炭化水素系化合物の中で, その末端に固体表面と 化学的相互作用をする官能基を持つ化合物は, 容易に固

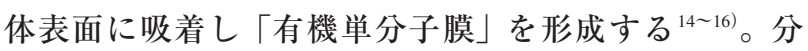
子末端にトリクロロシリル基, あるいはトリアルコキシ シリル基を有する飽和炭化水素系化合物（有機シラン化 合物）は種々の材料表面で吸着・重合し有機シラン単分 子膜を形成でき, ガラスやシリコンウエハー ${ }^{17)}$, 金属酸 化物固体 ${ }^{18)}$ などの種々の無機材料表面や, ポリ（ビニル アルコール ${ }^{19)}$, セルロース ${ }^{20)}$ などの高分子材料表面に も化学的・力学的に安定な膜を形成する。

有機シラン化合物の一つの利点は化学気相吸着 (CVA）法 ${ }^{21,22)}$ と真空紫外光リソグラフィーを組み合わ せることで容易に任意の二次元パターン化異種高分子ナ 
ノフィルムを調製できる点にある（Fig. 5)。筆者らは $\mathrm{CVA}$ 法により調製したフルオロアルキルシラン $\left[\mathrm{CF}_{3}\right.$ $\left(\mathrm{CF}_{2}\right)_{\mathrm{n}-1} \mathrm{CH}_{2} \mathrm{CH}_{2} \mathrm{Si}\left(\mathrm{OCH}_{3}\right)_{3}, \mathrm{n}=6,8 ; \mathrm{CF}_{\mathrm{n}}$ ] 単分子膜に対 し， $5 \mu \mathrm{m}$ および $10 \mu \mathrm{m}$ のライン状のフォトマスクを介 して真空紫外光を 10 分間照射し，単分子膜を局所光分 解させることで $\mathrm{CF}_{\mathrm{n}} / \mathrm{Si}-\mathrm{OH}$ ラインパターンを形成し た ${ }^{23)}$ 。な㧍，さらに露出した $\mathrm{Si}-\mathrm{OH}$ 部分に第二成分を 再びCVA で形成することにより, ライン状 2 成分系単 分子膜も調製可能である ${ }^{24)}$ 。

Fig. 6 は $\mathrm{CF}_{6} / \mathrm{Si}-\mathrm{OH}$ のラインパターン単分子膜固定化 基板をライン方向とラインに対して垂直方向に傾斜した ときの水滴の形状と動的接触角および転落角である。水 滴の転落角はラインと平行方向では $27^{\circ}$ であったのに対 し，垂直方向は $80^{\circ}$ であった。ここで, $\mathrm{CF}_{\mathrm{n}}$ 単分子膜と 局所分解により露出した $\mathrm{Si}-\mathrm{OH}$ の部分の高低差は $1 \mathrm{~nm}$ 以下であり, ライン幅 $(5 \mu \mathrm{m})$ に比べてはるかに小さ いため, 表面の凹凸の影響は殆ど無視できる。一方,
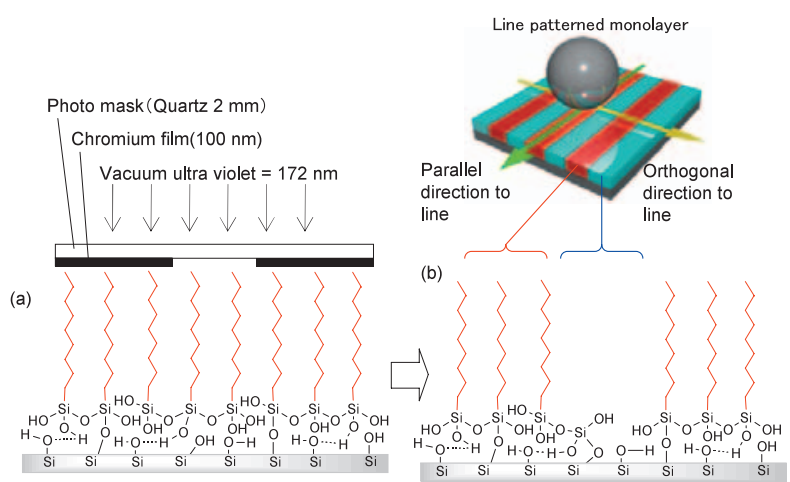

Fig. 5. (color online). Schematic view of (a) organosilane monolayer prepared by chemical vapor adsorption method and (b) line-patterned organosilane monolayer fabricated by vacuum ultraviolet photolithography.

(b) Orthogonal direction to line
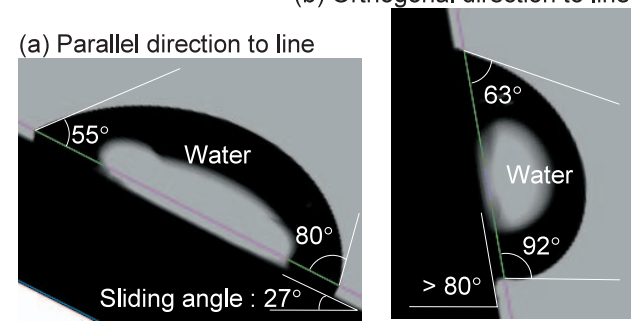

Fig. 6. (color online). Optical micrographs of the dynamic wetting for a water droplet $(20 \mu \mathrm{L})$ on a perfluoroalkylsilane/Si-OH patterned surface with $5 \mu \mathrm{m}$ of line and space : (a) parallel direction to line ; (b) orthogonal direction to line.
$\mathrm{CF}_{6} / \mathrm{Si}-\mathrm{OH}$ の表面自由エネルギー差は $62.2 \mathrm{mN} / \mathrm{m}$ であ る。つまり, ラインパターンに対して垂直方向に水滴が 進むためにはエネルギー障壁が大きく, 接触線が固定さ れるため, 高い転落角と前進接触角を示したと説明でき $ろ^{25)}$ 。

さらにこの親・踈水ラインパターン表面基板を環境制 御型走查電子顕微鏡内で泠却し, 水蒸気に暴露するとラ イン状に露出した親水性のシリコン基板に沿って水が楚 縮した（Fig. 7)。この技術は霧から水を捕集する材料や インクジェット基板 ${ }^{26}$ などへの展開が期待される。

\section{2 ポリマーブラシによる親疎水性制御}

ポリマーブラシは高分子鎖の一端が共有結合など比較 的強固な結合で基板表面につなぎ止められているため, 摩擦や洗浄に対して剥離しにくく ${ }^{27)}$, 改質効果を長期に わたって保持することが可能であるという特長がある。 最近では，基板表面に重合の開始剂を固定化し，そこか らモノマーを重合する「grafting-from」法が用いられ，

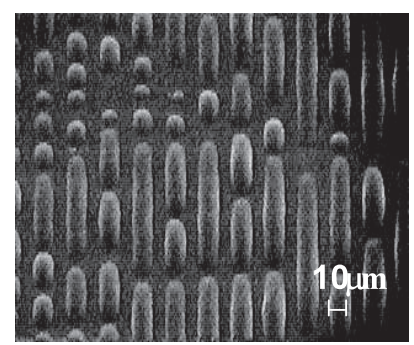

Fig. 7. Environmental SEM image of water condensation on hydrophilic part of a perfluoroalkylsilane/Si-OH line-patterned surface.

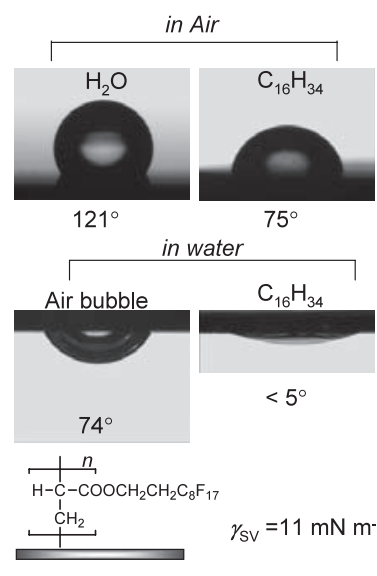

(a) Poly\{2-(perfluorooctyl)ethyl acrylate\} brush

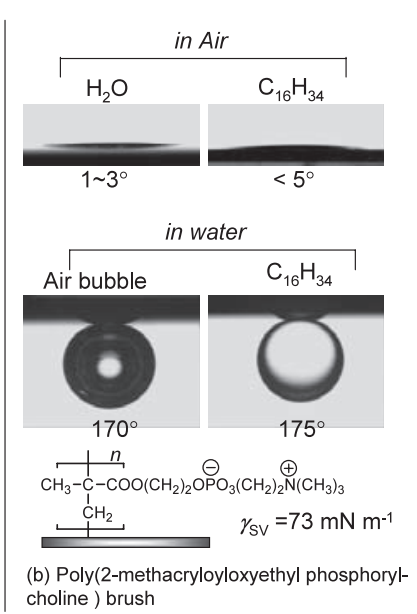

Fig. 8. Contact angles of water and hexadecane in air and air bubble and hexadecane in water on the surfaces of (a) poly\{2-(perfluoroocryl)ethyl acrylate $\}$ brush and (b) poly(2-methacryloyloxyethyl phosphorylcholine) brush. 
特にリビングラジカル重合法を適用した方法ではグラフ 卜密度が高く様々な官能基を有するポリマーブラシが調 製されている ${ }^{28)}$ 。Fig. 8 は表面開始原子移動ラジカル重 合で調製した側鎖に撥水性のフルオロアルキル基を有す る $\mathrm{PFA}-\mathrm{C}_{8}$ ブラシ薄膜 ${ }^{24)}$ と, リン脂質の親水基を側鎖に 有する双性イオン形メタクリレート系ポリマーブラシ薄 膜表面での空気中に扔ける水とへキサデカンの接触角で ある29)。 $\mathrm{PFA}-\mathrm{C}_{8}$ ブラシ薄膜表面では, フライパンなど にコーティングされているテフロンと同様に水の接触角 は大きく, ヘキサデカンなどの油の接触角も比較的大き い。一方, 双性イオン形メタクリレート系ポリマー表面 では水との親和性が強いため, 水の接触角は小さく表面 に広がろうとする ${ }^{30)}$ 。また, ヘキサデカンは空気との界 面自由エネルギーを低下させるために濡れ広がろうとす る傾向を示す。

水中での固体表面の濡れ性は医用高分子材料, バイオ チップなどの応用で極めて重要である。空気中で撥水性 を示す表面は水中では水との界面の自由エネルギーが高 く, 界面自由エネルギーを低下させるために水溶液中の 成分を吸着し界面を安定化しょうとする。固体/水界面 での表面の特性を評価するためには水和状態で接触角測 定を行う。この方法は Captive bubble 法とよばれ, $n$-ア ルカンあるいは気泡が接触角測定に用いられる ${ }^{31,32) 。 ~}$ Fig. 2（b）のように試料は水中に固定され，下方より液 滴あるいは気泡を試料表面に導入し接触角を測定する。

Fig. 8 に示すように水中では $\mathrm{PFA}^{-\mathrm{C}_{8}}$ ブラシ薄膜にお ける気泡の接触角は $74^{\circ}$ と低く, ヘキサデカンは界面エ ネルギーを低下させるために濡れ拡がろうとする。すな わち水中では油が付着しやすい。一方, 双性イオン形メ タクリレート系ポリマーブラシ薄膜表面では気泡もへキ サデカンもその接触角は $180^{\circ}$ に近く, まるで表面が水 で覆われたように気泡や炭化水素系液体が付着しにく い。これはカタッムリの殼の防污機構とよく似ている。 カタッムリの殼表面は親水性微細構造に水の薄い層を有 しているため污れが付着しても污れは水に浮いており， 水をかければ容易に污れが流れ落ちる仕組みを持ってい る。本研究で用いたポリ（2-メタクリロイルオキシエチ ルホスホリルコリン）（PMPC）は細胞外膜を構成する リン脂質分子と同様のホスホリルコリン基を有するた め，蛋白質や細胞を付着しにくく生体適合性材料として 用いられている ${ }^{33}$ 。固体材料表面を生体適合性のリン脂 質骨格を有する水溶性高分子で表面修飾することで ${ }^{34)}$, バイオエンジニアリング等に有用な新規機能材料へも展 開が行われている。

\section{4. 親水性ポリマーブラシのトライボロジー 特性}

親水性ポリマーブラシは環境に優しい水潤滑や, 大気 中の水蒸気の吸着による自己潤滑特性が注目される。親 水性表面が湿潤条件下で示す低摩擦掞よび潤滑は, 関節 の軟骨表面や眼球の表面など身体の中でも見受けられる

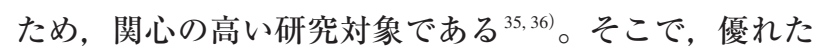
親水性を示すホスホリルコリン基を有するポリマーブラ シの水潤滑特性を検討した。

Fig. 9 は大気中, 水中, トルエン中で PMPC ブラシ ${ }^{30)}$ 表面をガラス球で摩擦した時の動摩擦係数である。 PMPC ブラシ薄膜の膜厚は乾燥状態で約 $30 \mathrm{~nm}$ である。 ガラス球を室温（298 K）にて垂直荷重 $0.49 \mathrm{~N}$ (応力換 算 $137 \mathrm{MPa})$, 滑り速度 $10^{-5}-10^{-1} \mathrm{~ms}^{-1}$, 振幅 $20 \mathrm{~mm}$ の 条件にて直線摺動させることで動摩擦你数を測定した。 乾燥窒素䨌囲気下ではガラス球と PMPC との相互作用 が大きく比較的高い動摩擦係数を示したが, 大気中の湿 度が上昇するとともに低下した。これは, 双性イオン型 高分子電解質 PMPC の吸湿性, 保水性が極めて高いた め, 大気中でも吸着水による潤滑がブラシ表面にて生じ ていたためである。つまり，ポリマー鎖の水和により摩 擦プローブと凝着力が弱く低摩擦となったと考えられ る。しかし, 水中に抒いては再び動摩擦係数の上昇が認 められた。この場合, 良溶媒である水中に PMPC ブラ シが浸されることで高い浸透圧が発生し, ポリマーブラ シは伸長した構造をしていることが中性子反射率測定 ${ }^{37)}$ や $\mathrm{AFM}^{38)}$ より明らかにされていることから, ブラシ層 が膨潤することによりガラス球との接触面積が増大し,

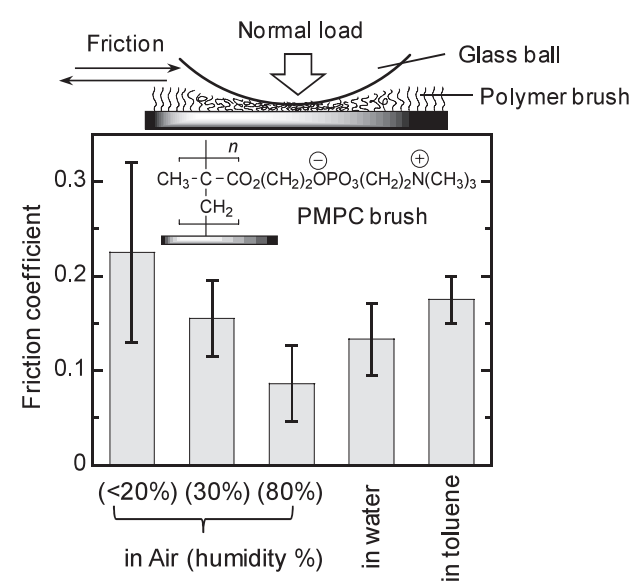

Fig. 9. Friction coefficients of poly(2-methacryloyloxyethyl phosphorylcholine) brush in air, water, and toluene by sliding a glass ball probe under the load of $0.49 \mathrm{~N}$ at a rate of $1.5 \times 10^{-3} \mathrm{~ms}^{-1}$. 
動摩擦係数が湿潤大気中よりも高くなったと考えられ る。ただし，このような現象は PMPC ブラシに独特の 現象であり, 他の親水性ポリマーブラシでは湿潤大気中 よりも水中の方が低摩擦係数を示す。また, PMPC に対 して貧溶媒のトルエン中ではさらに動摩擦係数が増大し た。これはポリマー鎖が貧溶媒分子との接触を好まず, 相対的にプローブとの接触が強くなり表面凝着力が増大 したこと, そしてブラシの収縮に伴うブラシ薄膜のせん 断強度の変化が動摩擦係数の上昇をもたらしたと考えら れる。

ガラス球表面にも基板と同じ種類のポリマーブラシを 固定し, ポリマーブラシ同士による摩擦を行うとさらに 動摩擦係数は低下する。Fig. 10 は水中における PMPC ブラシの動摩擦係数の速度依存性を示したものである。 摩擦速度 $10^{-5}-10^{-3} \mathrm{~ms}^{-1}$ にて動摩擦係数はほぼ一定の 值 (0.10-0.12) を示すが, $10^{-3} \mathrm{~ms}^{-1}$ 付近で急激に動摩 擦係数は 0.06 まで低下し, $10^{-3} \mathrm{~ms}^{-1}$ 以上の速度では 0.03 程度まで低下した。これは滑り速度の増加とともに ブラシ層間に水の流体润滑膜が形成することで, 境界潤 滑から混合潤滑状態となり, 動摩擦係数が低下したと考 えられる。表面未修飾のガラスとシリコン基板との摩擦 に拈いても動摩擦係数の低下が認められるが, 全ての摩 擦速度領域に扔いて動摩擦係数は 0.12 以下になること はなかったことから, 膨潤ポリマーブラシが適切な潤滑 層として機能していることがわかる。

また, 高密度に共有結合でグラフトされているポリマ ーブラシは低摩擦係数を示す環境において摩耗しにくい 特徴もある。スピンコート薄膜やグラフト密度の低いブ

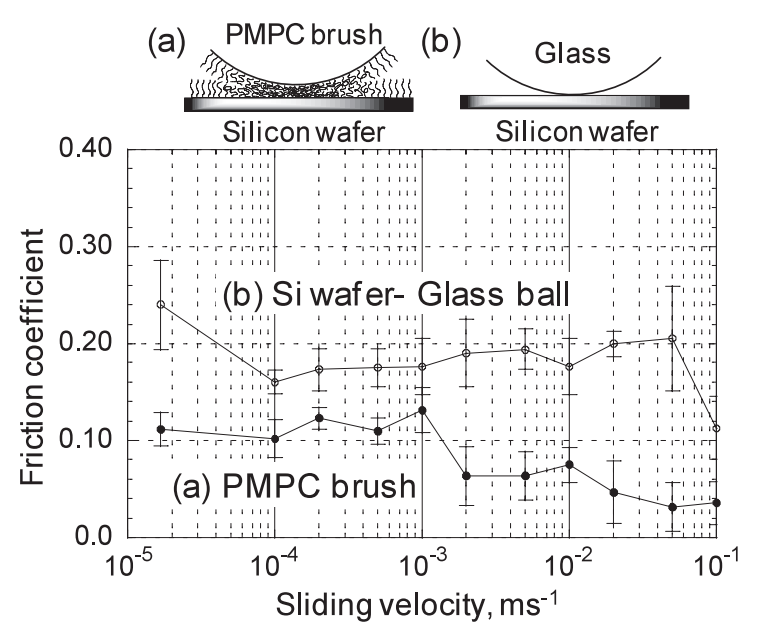

Fig. 10. Sliding velocity dependence of friction coefficient of (a) PMPC brush pair and (b) non-modified glass-silicon pair in water under a load of $0.20 \mathrm{~N}$ at 298 K.
ラシ薄膜が数回の摩擦で剥離するのに比べ, 高密度ブラ シは数十〜百回の摩擦においてもブラシ薄膜は残存して いることが明らかとなっている27,30)。

\section{5. 結}

論

本稿では自然界で利用されている撥水性や濡れ特性の 発現機構を種々の高分子薄膜表面へ適用することで濡れ 性や摩擦特性の制御を試みた。まず, 疎水性のワックス を主成分とする微細な凹凸構造により蓮の葉が撥水性を 示すことから，フッ素系ポリマー表面にナノインプリン 卜法により $500 \mathrm{~nm}$ ピッチ幅の凹凸構造の作製し, 撥水 性の向上を図った。また，有機単分子膜を用いて調製し た親・踈水性のコントラストを持つ幅 5-10 $\mu \mathrm{m}$ 程度の ラインパターン表面では, 液滴が異方性濡れおよび位置 選択的な濡れを生じることが示された。さらに, リン脂 質分子の極性基を側鎖に持つポリマーを高密度に表面に グラフトする（ポリマーブラシを形成）ことで超親水性 表面が得られた。また, このポリマーブラシは湿潤条件 下で水潤滑による低摩擦効果が認められ, 環境に優しい 水潤滑への応用が期待される。

\section{謝 辞}

本稿で述べた内容の一部は森田正道氏（現, ダイキン 工業), 本田幸司氏 (現, 兵庫県立工業センター) なら びに九州大学工学府物質創造工学専攻 山口央基氏の研 究成果であり,ここに心から深謝申し上げます。MPC をご提供頂いた東京大学大学院マテリアル工学専攻 石 原一彦教授に厚く御礼申し上げます。また, 本研究の一 部は文部科学省 21 世紀 COE プログラム「分子情報科学 の機能イノベーション」ならびにグローバル COE プロ グラム「未来分子システム科学」の援助を頂き, ここに 付記して感謝申し上げます。

\section{文献}

1) K. Koch, H.F. Bohn and W. Barthlott : Langmuir 25, 14116 (2009).

2) A.R. Parker and C.R. Lawrence : Nature 414, 33 (2001).

3) K. Autumn, Y.A. Liang, S.T. Hsieh, W. Zesch, W.P. Chan, T.W. Kenny, R. Fearing and R.J. Full : Nature 405, 681 (2000).

4) D.K. Owens and R.C. Wendt : J. Appl. Polym. Sci. 13, 1741 (1969).

5) S. Wu : J. Polym. Sci. Part C Polym. Symp. 45, 19 (1971).

6) S. Wu and K.K. Brzozowski : J. Colloid Inter. Sci. 37, 686 (1971).

7) C.J. van Oss, M.K. Chaudhury and R.J. Good : Chem. Rev. 88, 927 (1988). 
8) C. Ozcan and N. Hasirci : J. Appl. Polym. Sci. 108, 438 (2008).

9) F. Barroso-Bujans, R. Serna, E. Sow, J.L.G. Fierro and M. Veith : Langmuir 25, 9094 (2009).

10) R.N. Wenzel : Ind. Eng. Chem. 28, 988 (1936).

11) A.B.D. Cassie and S. Baxter: Trans. Faraday Soc. 40, 546 (1944).

12) K. Honda, M. Morita and A. Takahara: Soft Matter 4, 1400 (2008).

13) K. Honda, M. Morita, H. Masunaga, S. Sasaki, M. Takata and A. Takahara : Soft Matter 6, 870 (2010).

14) H.R. Tredgold: "Order in Organic Thin Films" (Cambridge Univ. Press, 2005).

15) R.G. Nuzzo and D.L. Allara: J. Am. Chem. Soc. 105, 4481 (1983).

16) E.S. Gawalt, C. Lu, S.T. Bernasek and J. Schwartz: Langmuir 15, 8929 (1999).

17) J. Sagiv : J. Am. Chem. Soc. 102, 92 (1980).

18) B. Watts, L. Thomsen, J.R. Fabien and P.C. Dastoor : Langmuir 18, 148 (2002).

19) H.S. Mansur, R.L. Oréfice and A.A.P. Mansur : Polymer 45, 7193 (2004).

20) M. Castellano, A. Gandini, P. Fabbri and M.N. Belgacem : J. Colloid Interface Sci. 273, 505 (2004).

21) K. Hayashi, N. Saito, H. Sugimura, O. Takai and N. Nagagiri : Langmuir 18, 7469 (2002).

22) A. Takahara, Y. Hara, K. Kojio and T. Kajiyama: Coll. Surf. B 23, 141 (2002).

23) M. Morita, T. Koga, H. Otsuka and A. Takahara : Langmuir 21, 911 (2005).

24) H. Ishida, T. Koga, M. Morita, H. Otsuka and A. Takahara : Tribology Lett. 19, 3 (2005).
25) J.P. Yongblood and T.J. MacCarthy : Macromolecules 32, 6800 (1999).

26) M. Morita, S. Yasutake, H. Ishizuka, J. Fukai and A. Takahara : Chem. Lett. 34, 916 (2005).

27) H. Sakata, M. Kobayashi, H. Otsuka and A. Takahara : Polym. J. 37, 767 (2005).

28) R.C. Advincula, W.J. Brittain, K.C. Caster and J. Rühe : "Polymer Brushes" (Wiley-VCH, Weinheim, 2004).

29) H. Yamaguchi, K. Honda, M. Kobayashi, M. Morita, H. Masunaga, O. Sakata, S. Sasaki and A. Takahara : Polym. J. 40, 854 (2008).

30) M. Kobayashi, Y. Terayama, N. Hosaka, M. Kaido, A. Suzuki, N. Yamada, N. Torikai, K. Ishihara and A. Takahara : Soft Matter 3, 740 (2007).

31) W.C. Hamilton : J. Collid Int. Sci. 40, 219 (1972).

32) K. Nakamae, T. Miyata and N. Ootsuki : Makromol. Chem. Rapid Commun. 14, 413 (1993).

33) K. Ishihara, T. Ueda and N. Nakabayashi : Polym. J. 22, 355 (1990).

34) Y. Iwasaki and K. Ishihara : Anal. Bioanal. Chem. 381, 534 (2005).

35) S. Lee and N.D. Spencer : Science 319, 575 (2009).

36) M. Kobayashi, Z. Wang, Y. Matsuda, M. Kaido, A. Suzuki and A. Takahara: Tribological Behavior of Polymer Brush "Prepared by the "Grafting-from" Method, in "Polymer Tribology" ed. by S.S. Kumar (Imperial College Press, London, 2009), pp. 582-602.

37) M. Kobayashi, Y. Terayama, M. Hino, K. Ishihara and A. Takahara : J. Phys. : Conf. Ser. 184, 012010 (2009).

38) Y. Terayama, M. Kikuchi, M. Kobayashi, M. Hino and A. Takahara : J. Phys. : Conf. Ser. 184, 012011 (2009). 